\title{
Introduction of Tallulolona's Life Philosophy in Local Content Learning Materials in Primary Schools to Preserve Toraja Local Wisdom
}

\author{
Dina Gasong* \\ Chiristian University of Indonesia Toraja, Toraja, Indonesia \\ Selvi Rajuaty Tandiseru \\ Chiristian University of Indonesia Toraja, Toraja, Indonesia
}

\begin{abstract}
Aesthetics and logic are inherent in the field of philosophy. Besides that, metaphysics and epistemology are also inseparable parts of philosophy. Philosophy seeks the truth of a tradition, its origins. Tallulolona is a tradition adopted by successive generations of the ancestors of the Toraja people for centuries. Tallulolona reveals the origins of the life of the Toraja in relation to the universe, and animals, which must be guarded by humans, so that it always creates universal harmony. It is the understanding of the Toraja tradition that their humans, plants and ancestral animals are brothers in the process of creation by the all-powerful being called 'Sauan Sibarrung'. That they are sangserekan, meaning that humans, animals and plants in the creation by Puang Matua are brothers. Therefore, humans must maintain the continuity of their brothers' lives to maintain universal harmony. However, the condition of universal harmony at this time has been neglected, so that the lives of humans, plants and animals no longer reflect sangserekan, in fact the current generation no longer even knows the value of this sangserekan. The research method used in this study is descriptive-qualitative, whose data is in the form of discourse or text. This descriptive-qualitative research with an ethnographic study approach, because it relates to local culture whose data is taken from informants. Qualitative research methods are carried out in natural settings, and the data collected is qualitative. Qualitative methods are more based on phenomenological philosophy that prioritizes lived experience. The result of this study is the compilation of a textbook for elementary school students, containing tallulolona philosophy that will be used in learning adapted to simple children's language and providing interesting pictures so that students like to read it. Elementary school students are a national generation that are very suitable according to their stage of development to instill cultural values.
\end{abstract}

Keywords: Philosophy, tallulolona, learning, local wisdom, teaching materials, elementary school

DOI: $10.7176 / \mathrm{JCSD} / 47-05$

Publication date: April $30^{\text {th }} 2019$

\section{Introduction}

Fundamentally understanding life-view is very important. The importance of understanding this life-view is that it becomes a guide in carrying out daily activities. The life-view becomes a guide in carrying out each activity so that an activity can be carried out properly. Discussing a life-view can not be separated from its source, namely philosophy. Philosophy is the mother of all science. Philosophy means thinking and feeling deeply about everything to the core of the problem. The word philosophy comes from the word philo which means love, and the word sophos which means science or wisdom. Based on this understanding it can be concluded that philosophy means love of science or wisdom (Akkase Teng, 2018). In discussing philosophy, an important element is culture. Culture contains the noble values of a region or nation. Akkase Teng (2018) argues that culture is important for the development of education, so it can preserve and develop the noble values of national culture.

Education is a fundamental requirement of people in the nation, both individually and together. In simple terms education can be defined as a conscious effort to increase human dignity. As stated by Yusufhadi Miarso (2004), instruction is the effort to manage the learning environment intentionally so that someone shapes themselves positively in certain positive conditions. And teaching is an effort to guide and direct the learning experience for students which usually takes place in a formal situation. The process of education and learning involves various interrelated components. These components are learners, students, teaching materials, conditions, methods, results. To get good results from an education, it must touch on three domains, namely the cognitive, affective, and psychomotor domains. The educational phenomenon in Indonesia in recent times tends to refer to the cognitive domain, and touches little on the affective and psychomotor domains.

Responding to this tendency, it is necessary to touch on the affective domain through learning the noble values of our ancestors, which are the local wisdom of each region in Indonesia. According to Shifa (2018), local wisdom is everything that becomes the potential of a region. In addition, local wisdom is also the result of human thought as well as the results of human works that have wise and prudent values. These values are 
inherited from generation to generation, so that they become a characteristic of an area. Local wisdom values are included in the affective domain. The affective domain concerns awareness of the importance of wisdom taught through learning local culture at school. The local wisdom values will help students to understand each concept in the material, so that what is provided by the knowledge gained by students is not just the knowledge itself, but also their ability to implement it in practical form outside of school (Shifa: 2018). Local wisdom is a strong foundation to counteract the effects of globalization. Understanding local wisdom values makes the nation's generation strong and resilient to external influences. Ramdani (2018) revealed that local wisdom is a culture that is owned by a particular society which is considered capable of surviving in the face of globalization, because local knowledge has values that can be used as a means of building national character.

Local wisdom values will ultimately shape the character of an area. These wisdom values are wrapped up in the culture of a region. The national identity is determined by national cultural values. This is contained in the Master Design of the National Character-Building Development of the Government of the Republic of Indonesia in 2010-2025. If you do not pay attention to cultural values, then the following will happen: (1) Disorientation and failure to live up to the values of Pancasila as the philosophy and ideology of the nation; (2) Limitations to the degree of integrated policies in realizing the essential values of Pancasila; (3) shifting ethical values in the life of the nation and state; (4) waning awareness of the values of national culture and state; (5) threat of nation's disintegration; (6) the weakening of the nation's independence. Ramdani (2018) argues that the effort to develop national character rests on Indonesian cultural values for national identity certainty.

Carrying out local cultural learning is based on the phenomena of morals that have begun to decline. In addition, local culture has not been optimized as a means of national character education. Based on that, there are two things that are the basis for the need to teach local cultural values to the nation's generation, namely: (1) the emergence of the phenomenon of moral degradation by decreasing character among students; (2) the values of a typical Indonesian society have not been optimized as a means of character education in Indonesia (Ramdani, 2018).

For character education in schools, Ramdani suggests three approaches, namely: (1) cognitive development / moral education approach, namely to know what is good; (2) caring approach which is an approach that emphasizes wanting what is good; (3) traditional character approaches that see good conduct as a fundamental in class practice and character education programs are integrated.

There are four basic characteristics in character education as stated by Foester in Suardi (2018) as follows: (1) order; that is, each action is measured based on a value hierarchy. Values are normative guidelines for each action; (2) coherence; namely the courage to stick to principle. Dare to take risks and not be tossed around in new situations. Coherence is the basis for building mutual trust. Without coherence it can undermine one's credibility; (3) autonomy; this characteristic means that someone is able to integrate rules from the outside to become personal values. It can be seen in the ability to make personal decisions without being affected by other parties or others; (4) firmness and loyalty; firmness is the ability of a person to keep going in order to expect what is considered good. Basic loyalty out of respect for selected commitments. That character determines the form of a person in all their actions. If these four characteristics of character education are found, then it can increase students' awareness of the introduction of eastern cultures that have long been upheld by our ancestors and founding fathers.

Universally various characters are formulated as shared life values based on these pillars:

a) Peace, b) Respect, c) Cooperation (cooperative), d) Freedom, e) Happiness,

f) Honesty (honesly), g) Simplicity, h) Tolerance, i) Unity In developing teaching materials.

\section{Research Methods}

The research method used in this study is descriptive-qualitative, whose data is in the form of discourse or text. This descriptive-qualitative research is combined with an ethnographic study approach, because it relates to local culture whose data is taken from informants. Qualitative research methods are carried out in natural settings, and the data collected is qualitative. Qualitative methods are more based on phenomenological philosophy that prioritizes lived experience.

\section{The Philosophy of Tallu Lolona in Toraja Culture}

In Toraja culture there is found the philosophy of tallu lolona, a'pa 'oto'na. Tallu lolona means the three bases of life, namely humans, plants, and animals. Of these three, lolo tau (humans) is the most holy. According to Sandarupa (2014), in the text of the creation myth the world consists of two parts, namely the journey of the gods and the teachings of the religion in the heavens (lalanna sukaran aluk), and the ancestral journey on earth (lalan $a d a^{\prime}$ ). The text of creation constructs that both human and animal and plant ancestors came from the same source (sauan sibarrung), and they are brothers (sangserekan). But after going down to earth they carry out their functions differently.

At first Puang Matua created a group complete with eight ancestors (to sanda karua), namely the human 
ancestor (Datu Laukku'), the ancestor of the Antiaris tree (Allo Tiranda), the ancestor of cotton (laungku'), the rainmother (pong pirik-pirik), the bird ancestor (Menturini), the buffalo ancestor (Manturini), the iron ancestor (riako), and the ancestor of rice (takkebuku). The remnants of his creation are poured into valleys which later grow as forests. The essence of the teachings in this text, say the elders, is that humans cannot be greedy and treat nature arbitrarily because they are brothers.

Before entering the forest (pangngala' tamman), a ceremony must be carried out to ask permission from the ancestors concerned so as not to cause death. The management of the relations of various elements of the cosmos which are regulated by Aluk comes from religious teachings (sukaran aluk) which include the aluk ceremonies, prohibitions (pemali), general truths (sangka'), and events according to their flow (salunna). In the myth of the first human descent (Pong Mula Tau) in Rura (now Enrekang) Tangdilino told Pong Bulu Kuse and Pong Sabannnangna to enter the forest to cut down trees without performing ceremonies, so all the trees mentioned the name that causes death (kada beko) to humans if they cut it down. Greed towards nature is a sign of nonbrotherly relations. The reproduction of the anak dara-anak muane relations, sibling relations, appear in the deadly words (kada beko), and the life-giving words (kada tuo). If humans use trees that are in the forest without conducting mediation (the likaran biang ritual), namely the ceremony of life by sacrificing chickens in the forest, then it will cause difficulties for humans. Conversely, if you are going to use wood from the forest for human needs by carrying out the likaran biang ritual, then the trees will provide sustenance.

\section{The Philosophy of Tallu Lolona in Toraja Culture}

To follow up on the FGD results, tallulolona teaching material was prepared for elementary school students. The following briefly describes the contents of the textbook. Theme of the lesson: Toraja Culture

Teaching materials 1. Introduction to Toraja Culture in general.

Basic competencies:

1. Students can mention the types of Toraja culture

2. Students can mention activities from culture related to celebration (rambu tuka')

3. Students can mention activities from mourning culture ( $r a m b u$ solo')

Brief description of Toraja culture: This material will be discussed for three meetings. In the first discussion, each student memorizes a hundred words or terms in the Toraja language. In the second meeting two types of Toraja culture are discussed in broad outline, namely the culture of rambu tuka' related to celebration, and the culture of rambu solo' related to mourning. At the third meeting the students mention five activities carried out in the rambu tuka' and five activities carried out in rambu solo'.

Teaching material 2. Introduction to the Culture of tallu lolona

Basic competencies:

1. Students can tell about the cultural history of Tallulolona

2. Students can mention the tallulolona component

The material description on the second theme is discussed in two meetings. The first meeting discusses the origins of the philosophy of tallulolona. Students can tell that all living things in this world are sourced from the same source, so that all of them are siblings who must take care of one another. The second meeting discusses the components of tallulolona, namely humans, animals and plants. Humans are siblings with animals and plants, and because they are siblings, they must take care of each other.

Teaching materials 3. Introduction to lolo tau culture

Basic competencies:

1. Students can tell the meaning of lolo tau

2. Students can tell about lolo tau activities in the environment

Description of the theme 3 introduction to lolo tau, discussed in two meetings. At the meeting, human life is told from birth to adolescence. At the second meeting, human activity is told from working to earn a living to dying.

Teaching materials 4. Introduction to lolo tatanan

Basic competencies:

1. Students can tell the meaning of lolo tatanan

2. Students can tell the connection between lolo tatanan and humans

Short description: this section describes how to grow crops, how to cut down forest trees, how to treat plants according to culture. The second meeting describes the use of plants for humans. How to use trees in the forest.

Teaching materials 5. Introduction to lolo patouan culture

Basic competencies:

1. Students can tell the meaning of lolo patuoan

2. Students can tell the connection between lolo patuoan and humans

Short description: with this theme students get stories about how to raise livestock, namely buffalo, pig, 
chicken, fish. Next the students get a story about the benefits of plants around the house, as well as those in the garden for humans.

Teaching materials 6. Students Traveling to Tourism Objects

Basic competencies:

Students can share experiences visiting tourist attractions

Short description: on this occasion the students are invited to do a tour of tourism to one of the objects near the school, then they are asked to describe whatever they saw in the tourist attraction.

\section{Conclusions and Recommendations}

In connection with the fact that tallulolona teaching materials as teaching materials for local content in elementary schools in Toraja does not yet exist, even though the teaching materials are needed for the preservation of the values of Toraja culture, so a policy is needed to support the procurement of these teaching materials. For this reason, teaching materials need to be designed as well as possible. To achieve this, it needs to be supported by policies by the local government of Tana Toraja and North Toraja.

Based on this, two things need to be recommended, namely:

a. Both the Tana Toraja and North Toraja local governments need to intervene in the formation of regulations and policies of the regional government to realize the provision of teaching materials for Tallulolona.

b. Sharpen understanding of tallulolona culture in all education in the Districts of Tana Toraja and North Toraja

\section{References}

Adriani, N. dan ALB. C. Kruijt, De Bare'e-Sprekende Toradja's van Midden-Celebes, Batavia, Landsdrukkerij, 1912.

Akkase Teng, H. Muhammad Bahar. Filsafat Kebudayaan dan Sastra (dalam Perspektif Sejarah). Jurnal Ilmu Budaya Volume 5, nomor 1, Juni 2017. ISSN 2354-7294

Bieshaar, W. 1901-1926, De Gereformeerde Zendingsbond Na 25 Jaren, Den Haag, Gedenboek, 1926.

Christou, Maria "Sisters and Others: The Power and Politics of Weaving Supplementary Weft Textiles in a Sa'dan Toraja Village", Textile Society of America Symposium Proceedings, 2012, Paper 667.

Christou, Maria An Ethnographic Study of the Loom and Weaving of the Sa'dan Toraja of To' Barana' (MA. Thesis, tidak dipublikasikan), Clothing and Textiles, Department of Human Ecology, University of Alberta, 1997.

Coakley, John W. Women, Men, and Spiritual Power: Female Saints and Their Male Collaborators, New York, Columbia University Press, 2006.

Crystal, Eric "Cooking Pot Politics: A Toraja Village Study”, Indonesia, 1974, No. 18, hal. 118-151.

Divan, Stefanus. Pengembangan Bahan Ajar Tematik Berbasis Budaya Lokal untuk Siswa kelas IV Sekolah Dasar. Jurnal Ilmu Pendidikan: Kajian Teoretik dan Praktik Pendidikan. ISSN 2549-7774 (online), ISSN 2548-6683 (print) $\quad$ http://journalsum.ac.id/index.php/jktpk.

Gasong, Dina. "Sejarah Daya Tarik Tana Toraja. Yogyakarta: Gunung Sopai, 2013.

Hicken, Andy "The Wishes of Your Parents": Power Ballads in Tana Toraja, Indonesia", Journal of Popular Music Studies, Vol. 22, Issue 2, 2010, hal. 198-218.

Hollan, Douglas W. dan Jane C. Wellenkamp, Contentment and Suffering: Culture and Experience in Toraja. New York, Columbia University Press, 1994.

Manta', Yohanis R. 'Sastra Toraja Kumpulan Kada-kada To minaa dalam Rambu Tuka' Rambu Solo', Rantepao:Sulo, 2011.

Nooy-Palm, H.M. "Introduction to the Sa'dan Toraja People and Their Country", Archipel, Vol. 10, 1975 , hal. 53-91. doi : 10.3406/arch.1975.1241.

Nooy-Palm, Hetty, The Sa'dan Toraja; A study of their social life and religion. Vol. I: Organization, Symbols and, Beliefs, The Hague, Marthinus Nijhoff. [KITLV, Verhandelingen 87.] 1979.

Nooy-Palm, Hetty, The Sa'dan Toraja; A study of their social life and religion. Vol. II: Rituals of the East and West, Dordrecht: Foris. [KITLV, Verhandelingen 118.] 1986.

Roosihermiatie, Betty et al. (Ed.), Buku Seri Etnografi Kesehatan Ibu dan Anak 2012: Etnik Toraja Sa'dan, Desa Sa'dan Malimbong, Kecamatan Sa’dan, Kabupaten Toraja Utara, Provinsi Sulawesi Selatan, Pusat Humaniora, Kebijakan Kesehatan dan Pemberdayaan Masyarakat, Badan Penelitian dan Pengembangan Kesehatan, Kementerian Kesehatan RI, 2012.

Ramdani, Eni. Model Pembelajaran Kontekstual Berbasis Kearifan Lokal sebagai Penguatan Pendidikan Karakter. Jurnal Pendidikan Ilmu-ilmu Sosial $10 \quad$ (1) (2018): 1-10. http://Journal.unimed.ac.id//2012/index.php/jupits

Sandarupa, Stanislaus. "Pembangunan Pariwisata Berbasis Tallu Lolona" disampaikan dalam Seminar Pariwisata Berbasis Tallu Lolona dalam rangkaian Toraja International Festival yang diselenggarakan oleh PEMDA Toraja di Ulu Salu Toraja pada tanggal 12 - 13 Agustus 2014. 
Shifa, Naela Khusna Faela. Pembelajaran Berbasis Kearifan Lokal di Sekolah Dasar (Sebuah Kerangka Konseptual). Inopendas Jurnal Ilmiah Kependidikan. Vol. 1 No. 1 Februari 2018 hal 48-53. ISSN 26155443.

Suardi. Pendidikan Karakter Berbasis Kearifan Lokal. Jurnal Pendidikan Sosiologi dan Humaniora.

Veen, H. van der, "The Merok Feast of the Sa'dan Toradja", Springer-Science+Business Media, B.V. , 1965.

Waterson, R. "Houses, Graves and the Limits of Kinship Groupings among the Sadan Toraja", Bijdragen tot de Taal-, Land- en Volkenkunde, 1995a, 151, no. 2, Leiden, hal.194-217.

Waterson, Roxana "Entertaining a Dangerous Guest: Sacrifice and Play in the Ma'pakorong Ritual of the Sa'danToraja", Oceania, 1995b, Vol. 66, No. 2, hal. 81-102.

Waterson, Roxana "The Contested Landscapes of Myth and History in Tana Toraja" dalam James J. Fox (ed.), The Poetic Power of Place: Comparative Perspectives on Austronesian Ideas of Locality, Canberra, ANU E Press, 2006.

Waterson, Roxana, Paths and Rivers: Sa'dan Toraja Society in Transformation, Leiden, KITLV, 2009.

Zerner, Charles "Signs of the Spirits, Signature of the Smith: Iron Forging in Tana Toraja", Indonesia, Vol. 31, 1981, hal. 89-112. 